\title{
CHARACTERISTICS AND BIODIVERSITY OF ENDOPHYTIC PHOSPHORUS- AND POTASSIUM- SOLUBILIZING BACTERIA IN MOSO BAMBOO (PHYLLOSTACHYS EDULIS)
}

\author{
ZONG-SHENG YUAN, ${ }^{1}$ FANG LiU2 ${ }^{2}$ and GuO-FANG ZHANG ${ }^{1}$ * \\ ${ }^{1}$ College of Forestry, Fujian Agriculture and Forestry University, Fuzhou 350002, Fujian, China \\ ${ }^{2}$ Mycological Research Center of Fujian Agriculture and Forestry University, \\ Fuzhou 350002, Fujian, China
}

(Received: March 13, 2015; accepted: April 27, 2015)

\begin{abstract}
Endophytic phosphorus- and potassium-solubilizing bacteria were screened from the root, rhizome, stem, and leaves of Moso Bamboo, and their diversity was analyzed using their 16S rDNA sequences. Twenty endophytic phosphorus and potassium-solubilizing bacteria were screened from 82 bamboo plants, among which the CT-B09-2, WYS-A01-1 and JL-B06 had higher activities in decomposing organophosphates. The three species showed a decomposition diameter/colony diameter (D/d) of 5.05, 4.19 and 2.95, respectively, and a solubilizing activity of $81.77 \mathrm{mg} / \mathrm{L}, 77.85 \mathrm{mg} / \mathrm{L}$ and $63.69 \mathrm{mg} / \mathrm{L}$, respectively. JL-B06, WYS-A01-1 and CT-B09-2 had higher activities in decomposing inorganic phosphorus, with a decomposition diameter/colony diameter (D/d) of 2.34, 2.12 and 1.82 , respectively, and a solubilizing activity of $30.58 \mathrm{mg} / \mathrm{L}, 38.89 \mathrm{mg} / \mathrm{L}$ and $48.35 \mathrm{mg} / \mathrm{L}$, respectively. CT-B21, WYS-A03-1 and JL-B06 had higher activities in decomposing potassium, with a decomposition diameter/colony diameter $(\mathrm{D} / \mathrm{d})$ of $3.37,4.84$ and 4.33 , respectively, and a solubilizing activity of $2.81 \mathrm{mg} / \mathrm{L}, 2.54 \mathrm{mg} / \mathrm{L}$ and $2.46 \mathrm{mg} / \mathrm{L}$, respectively. The $16 \mathrm{~S}$ rDNA sequence analysis showed that the 20 phosphorus- and potassium-solubilizing bacteria belong to 14 species from 10 genera, and mainly consist of Alcaligenes spp., Enterobacter spp. and Bacillus spp. Our results demonstrate the abundant diversity of endophytic phosphorus- and potassiumsolubilizing bacteria in Moso Bamboo.
\end{abstract}

Keywords: Phyllostachys edulis - endophytic bacteria - phosphorus- and potassium-solubilization - biodiversity

\section{INTRODUCTION}

Endophytic bacteria can colonize and conduct in plants for a long term but insusceptible to environmental conditions. They have a wide range of biological effects on plant growth and development, disease resistance, and reaction to adverse environments [23]. Up to 129 kinds of endophytic bacteria from 54 genera have been isolated from tomato, cotton, cucumber, corn, rice, and other plants, distributed throughout all plant tissues $[2,4,16,28]$. As a result, endophytic bacteria have great potential as natural biological resources.

Phosphorus and potassium are essential nutrients for plant growth, but phosphorus content is low in most soils and in an insoluble state $[12,24]$. Phosphate fertilizers

*Corresponding author; e-mail address: fjzgfzgf@126.com 
can easily form an insoluble state in soil $[17,26]$, while the majority of soil potassium also exists in the form of silicate minerals which cannot be absorbed by the plant. Therefore, full absorption of soil-based phosphorus and potassium by plants has important practical significance in promoting crop yield and quality, reducing the environmental impact of fertilizer, and improving the physical and chemical properties of soil. Soil phosphorus and potassium activation relies on the presence of microorganisms, and the solubilization of poorly soluble phosphorus and potassium by microbial species is gaining more and more attention [29]. Efficient phosphorus and potassium solubilizing bacterial strains can effectively convert insoluble phosphorus and potassium in soil into their soluble forms that can be taken up and utilized by crops [11]. In recent years, a large number of endophytic phosphorus- and potassiumsolubilizing bacterial strains have been identified through screens [6, 27], mainly from crops and soil $[18,22,25]$.

Moso Bamboo is an important forest resource in southern China. Research on Moso Bamboo has focused on improving yields, optimizing the physical and chemical properties of the soil, and studying the species diversity [3, 9]. Han et al. have screened and analyzed phosphorus-solubilizing bacteria from bamboo roots [8], but there is lack of study on the endophytic phosphorus and potassium-solubilizing bacteria in various bamboo tissues. In this study, the root, rhizome, stem, and leaves of bamboo from three different regions of Fujian, China were used to screen for endophytic phosphorus and potassium-solubilizing bacterial strains, and their 16S rDNA diversity was further analyzed in order to build up a database of phosphorus- and potassium-solubilizing bacteria, and to provide new evidence for the exploitation of plant growth-promoting bacteria.

\section{MATERIALS AND METHODS}

\section{Strains}

A total of 82 endophytic bacteria were isolated from the roots, rhizome, stem, and leaves of Moso Bamboo in each of the following regions: Wuyi Mountains (Wuyishan Xingcun Town), Jiangle (Longxi Mountain nature reserve, Jiangle County), and Changting (Sidu Town, Changting County), of which 29 were isolated from roots, 35 from the rhizome, 13 from the stem, and 5 from leaves.

\section{Cultivation medium and reagents}

Endophytic bacteria were cultured in nutrient agar (NA) culture medium containing $3 \mathrm{~g}$ beef extract, $5 \mathrm{~g}$ peptone, $5 \mathrm{~g} \mathrm{NaCl}, 18 \mathrm{~g}$ agar, and $1000 \mathrm{ml}$ water with $\mathrm{pH}$ 7.0-7.2.

Organophosphorus plate medium was made as follows: $10 \mathrm{~g}$ glucose, $0.5 \mathrm{~g}$ $\left(\mathrm{NH}_{4}\right)_{2} \mathrm{SO}_{4}, 0.3 \mathrm{~g} \mathrm{NaCl}, 0.3 \mathrm{~g} \mathrm{KCl}, 0.03 \mathrm{~g} \mathrm{MnSO}_{4}, 0.03 \mathrm{~g} \mathrm{FeSO}_{4}, 0.2 \mathrm{~g}$ lecithin, 
$5.0 \mathrm{~g} \mathrm{CaCO}_{3}, 0.4 \mathrm{~g}$ yeast extract, $20 \mathrm{~g}$ agar, $1000 \mathrm{~mL}$ distilled water, $\mathrm{pH}$ 7.0-7.2 (no agar for liquid medium).

Inorganic phosphorus plate medium was made as follows: $10 \mathrm{~g}$ glucose, $0.5 \mathrm{~g}$ $\left(\mathrm{NH}_{4}\right)_{2} \mathrm{SO}_{4}, 0.3 \mathrm{~g} \mathrm{NaCl}, 0.3 \mathrm{~g} \mathrm{KCl}, 0.03 \mathrm{~g} \mathrm{MnSO}_{4}, 0.03 \mathrm{~g} \mathrm{FeSO}_{4}, 0.3 \mathrm{~g} \mathrm{MgSO}_{4}, 5.0$ $\mathrm{g} \mathrm{CaCO}_{3}, 5.0 \mathrm{~g} \mathrm{Ca}_{3}\left(\mathrm{PO}_{4}\right)_{2}, 0.4 \mathrm{~g}$ yeast extract, $20 \mathrm{~g}$ agar, $1000 \mathrm{~mL}$ distilled water, $\mathrm{pH}$ 7.0-7.2 (no agar for liquid medium).

Potassium bacterial plate medium was made as follows: $10 \mathrm{~g}$ sucrose, $0.5 \mathrm{~g}$ yeast extract, $1.0 \mathrm{~g}\left(\mathrm{NH}_{4}\right)_{2} \mathrm{SO}_{4}, 0.5 \mathrm{~g} \mathrm{MgSO}_{4}, 1.0 \mathrm{~g} \mathrm{CaCO}_{3}, 1.0 \mathrm{~g}$ potassium feldspar powder, $15 \mathrm{~g}$ agar, $1000 \mathrm{~mL}$ distilled water, $\mathrm{pH}$ 7.0-7.2 (no agar for liquid medium).

An endophytic bacteria DNA extraction kit, primers, markers, reagents of PCR were purchased from Shenggong Biotechnology Co. Ltd. (Shanghai, China). All other reagents were analytically pure and made in Sinopharm Chemical Reagent Co., Ltd. (Shanghai, China).

\section{Determination of the effect of phosphorus- and potassium-solubilization on plate media (pre-screening)}

The isolated endophytic bacterial strains were inoculated in prepared organophosphate medium, inorganic phosphorus medium, and potassium medium bacterial culture plates. Four inoculation points were inoculated for each plate with three repeats, then they were cultured at $28{ }^{\circ} \mathrm{C}$ for $5 \mathrm{~d}$. Strains were recorded with respect to their growth and decomposition halo size. Based on the size of the decomposition halo, we determined the decomposition diameter/colony diameter $(\mathrm{D} / \mathrm{d})$ value of the endophytic phosphorus- and potassium-solubilizing bacteria. The larger the decomposition halo, the greater the $\mathrm{D} / \mathrm{d}$ value. The endophytic phosphorus and potassium-solubilizing bacteria strains were stored on NA slant medium.

\section{Determination of the effect of phosphorus- and potassium-solubilization in flask (re-screening)}

The selected phosphorus and potassium-solubilizing bacterial strains were seeded in NA liquid medium. Then, $5 \mathrm{~mL}$ of the bacterial suspension were inoculated in triplicate in $100 \mathrm{~mL}$ of liquid organic phosphorus medium, inorganic phosphorus medium, and potassium medium once the concentration of the bacterial suspension reached $10^{8}$ $\mathrm{CFU} / \mathrm{mL}$. A negative control was also prepared. After culturing at $28^{\circ} \mathrm{C}$ at $160 \mathrm{r} / \mathrm{min}$ for $7 \mathrm{~d}$, the strains were centrifuged at $4{ }^{\circ} \mathrm{C}$ at $10,000 \mathrm{r} / \mathrm{min}$ for $15 \mathrm{~min}$ and the supernatant was collected to determine the soluble phosphorus content and $\mathrm{pH}$ using antimolybdenum antimony colorimetry. The soluble potassium content was determined with the flame photometric method [15]. 


\section{S rDNA identification of endophytic bacteria}

After 24 hours incubation in liquid NA medium, DNA from the endophytic bacteria was extracted using the Bacterial Genome Extraction Kit (Shenggong Biotechnology Co. Ltd., Shanghai, China). The 16S rDNA gene sequences were amplified using universal primers 27F (5'-AGAGTTTGATCCTGGCTCAG-3') and 1492R (5'-GGTTACCTTGTTACGACTT-3').

PCR products were separated by $1 \%(\mathrm{w} / \mathrm{v})$ agarose gel electrophoresis and sent to Poshang Biotechnology Co. Ltd. (Shanghai, China) for sequencing. After determination of the DNA sequences, homologous sequence retrieval (the homologous sequences were deposited in $\mathrm{NCBI}$ ) and analysis were conducted using Blast software from NCBI (http:/www.ncbi.nlm.nih.gov/Blast/). The phylogenetic trees were constructed, and the taxonomic status of the strains were determined

\section{Statistical analysis}

Data were analyzed using Excel (Microsoft Corporation). The statistical analysis was conducted using SPSS18 software (Statistical Product and Service Solutions, International Business Machines Corporation, Armonk, New York City, USA).

\section{RESULTS}

\section{Pre-determination of bacterial phosphorus- and potassium-solubilizing activities}

The phosphorus- and potassium-solubilizing plate test showed that, after placing cultures on the organic phosphorus, inorganic phosphorus and potassium-solubilizing bacterial media plates for $5 \mathrm{~d}, 20$ out of 82 endophytic bacterial strains formed decomposition halos on all three types of media. And the 20 strains including 7 bacterial strains from the root, and accounting for $24.14 \%$ of total bamboo root endophytic bacteria (29); 10 bacterial strains from the rhizome, and accounting for $28.57 \%$ of total bamboo rhizome endophytic bacteria (35); Three bacterial strains from the stem, and accounting for $23.08 \%$ of total bamboo stem endophytic bacteria (13).

As shown in Table 1, 20 strains have organophosphorus-solubilizing activity. Specifically, the organophosphorus D/d value varied between $1.71-5.05$, and 7 endophytic bacterial strains (CT-B09-2, WYS-A01-1, WYS-B12, WYS-C01, WYS-C14, JL-B06, WYS-A03-1) had "++" (strong activity) organophosphorus activity. Fourteen strains showed activity against inorganic phosphorus, with the inorganic phosphorus $\mathrm{D} / \mathrm{d}$ value varied between 1.09-2.34, and 5 endophytic bacterial strains (JL-B06, CT-B09-2, WYS-A01-1, CT-B17, CT-A17) showed higher than "++" against inorganic phosphorus. Twenty strains had potassium-solubilizing activity with the value of D/d varied between 2.37-5.84, and 9 endophytic bacterial strains (CT-B17, WYS- 
Table 1

Pre-screening of efficient phosphorus- and potassium-solubilizing bacteria

\begin{tabular}{|l|c|c|c|c|c|c|}
\hline No. of strain & $\begin{array}{c}\text { Organic } \\
\text { phosphorus }\end{array}$ & $\begin{array}{c}\text { Decomposition } \\
\text { diameter/colony } \\
\text { diameter (D/d) }\end{array}$ & $\begin{array}{c}\text { Inorganic } \\
\text { phosphorus }\end{array}$ & $\begin{array}{c}\text { Decomposition } \\
\text { diameter/colony } \\
\text { diameter (D/d) }\end{array}$ & Potassium & $\begin{array}{c}\text { Decomposition } \\
\text { diameter/colony } \\
\text { diameter (D/d) }\end{array}$ \\
\hline WYS-A03-1 & ++ & $2.79 \pm 0.26$ & ++ & $1.09 \pm 0.01$ & ++ & $4.84 \pm 0.47$ \\
\hline WYS-A01-1 & ++ & $4.19 \pm 0.24$ & ++ & $1.82 \pm 0.33$ & ++ & $4.50 \pm 0.34$ \\
\hline WYS-C01-1 & ++ & $2.42 \pm 0.35$ & - & - & ++ & $4.33 \pm 0.47$ \\
\hline WYS-B12 & ++ & $3.73 \pm 0.53$ & + & $1.24 \pm 0.12$ & ++ & $4.81 \pm 0.46$ \\
\hline WYS-C01 & ++ & $3.50 \pm 0.38$ & + & $1.51 \pm 0.17$ & + & $3.05 \pm 0.15$ \\
\hline WYS-A02-2 & + & $1.71 \pm 0.25$ & - & - & + & $3.05 \pm 0.54$ \\
\hline WYS-C14 & ++ & $3.14 \pm 0.81$ & - & - & + & $3.03 \pm 0.38$ \\
\hline JL-A03 & + & $1.95 \pm 0.10$ & - & - & + & $3.58 \pm 0.57$ \\
\hline JL-D02 & + & $2.75 \pm 0.29$ & - & - & ++ & $3.00 \pm 0.01$ \\
\hline CT-A17 & + & $2.15 \pm 0.30$ & ++ & $1.31 \pm 0.20$ & + & $4.94 \pm 0.13$ \\
\hline CT-A03 & + & $3.29 \pm 0.50$ & + & $1.78 \pm 0.21$ & + & $4.88 \pm 0.14$ \\
\hline CT-B17 & + & $2.63 \pm 0.26$ & ++ & $1.90 \pm 0.12$ & ++ & $5.84 \pm 0.33$ \\
\hline CT-B20 & + & $2.74 \pm 0.39$ & + & $2.00 \pm 0.34$ & ++ & $4.39 \pm 0.80$ \\
\hline JL-A04 & + & $2.60 \pm 0.01$ & + & $1.42 \pm 0.10$ & + & $4.38 \pm 0.14$ \\
\hline CT-B04-1 & + & $3.04 \pm 0.67$ & + & $1.60 \pm 0.16$ & + & $5.59 \pm 0.17$ \\
\hline CT-B09-1 & + & $2.61 \pm 0.27$ & + & $1.71 \pm 0.12$ & + & $3.82 \pm 0.66$ \\
\hline CT-B09-2 & +++ & $5.05 \pm 0.41$ & ++ & $2.12 \pm 0.08$ & ++ & $3.30 \pm 0.36$ \\
\hline CT-B21 & + & $2.14 \pm 0.19$ & - & - & + & $2.37 \pm 0.17$ \\
\hline JL-B06 & ++ & $2.95 \pm 0.19$ & ++ & $2.34 \pm 0.18$ & ++ & $4.33 \pm 0.47$ \\
\hline CT-B13-1 & ++ & $2.11 \pm 0.14$ & + & $2.19 \pm 0.24$ & + & $4.25 \pm 0.50$ \\
\hline
\end{tabular}

Note: D: diameter of transparent circle; d: colony diameter. -: no activity (decomposition circle $<10 \mathrm{~mm}$ ) +: slight activity (decomposition circle: 10-15 mm); ++: strong activity (decomposition circle: 16-20 mm); +++ : high activity (decomposition circle: $>20 \mathrm{~mm}$ )

A03-1, WYS-B12, WYS-A01-1, CT-B20, JL-B06, WYS-C01-1, CT-B09-2, JL-D02) had potassium-solubilizing activity as high as "++".

\section{Pre-screening of efficient endophytic phosphorus- and potassium-solubilizing bacteria}

The content of soluble phosphorus in the culture medium measured using anti-molybdenum, antimony colorimetry showed that various bacterial strains has distinct organic phosphorus (lecithin) and inorganic phosphate (tricalcium phosphate)-solubilizing activities. For the 20 endophytic bacteria, $2.52-81.77 \mathrm{mg} / \mathrm{L}$ soluble phosphorus 
was released from $0.2 \mathrm{~g} / \mathrm{L}$ lecithin, and the control (CK, it was the liquid medium which did not contain any bacteria) of negative control was $1.54 \mathrm{mg} / \mathrm{L}$, the inoculated were 1.64-53.10 times higher. The strain CT-B09-2 in bamboo rhizome had the highest soluble phosphorus content of $81.77 \mathrm{mg} / \mathrm{L}$, while the endophytic bacteria WYSA02-2 in bamboo roots had the lowest soluble phosphorus content of $2.52 \mathrm{mg} / \mathrm{L}$. The 20 endophytic bacteria released $3.50-54.93 \mathrm{mg} / \mathrm{L}$ from $5.0 \mathrm{~g} / \mathrm{L}$ tricalcium phosphate, and their CK were 10-156.94 times that of the negative control, which was 0.35 $\mathrm{mg} / \mathrm{L}$. The strain WYS-B12 in bamboo rhizome had the highest soluble phosphorus content of $54.93 \mathrm{mg} / \mathrm{L}$, while the endophytic bacteria WYS-A02-2 in bamboo roots had the lowest soluble phosphorus content of $3.50 \mathrm{mg} / \mathrm{L}$. As shown in Figure 1, the tested strains had significantly different activities in decomposing lecithin and tricalcium phosphate.

It can be seen from the $\mathrm{pH}$ value of the organic and inorganic phosphorus media that, compared to CK, most inoculated strains showed a decrease in $\mathrm{pH}$. Specifically, the organic and inorganic phosphorus media had significantly lower $\mathrm{pH}$ with a reduction of 3.43 and 2.76, respectively. The correlation analysis of inoculated culture medium $\mathrm{pH}$ and soluble phosphorus content suggested a significant negative correlation between them, indicating that the lecithin and tricalcium phosphate solubility of tested strains was affected by the $\mathrm{pH}$ of the culture medium. When the culture medium becomes more acid, the soluble phosphorus was released by endogenous bacteria from lecithin and tricalcium phosphate increased, which was consistent with a previous report by Zhao et al. [30].

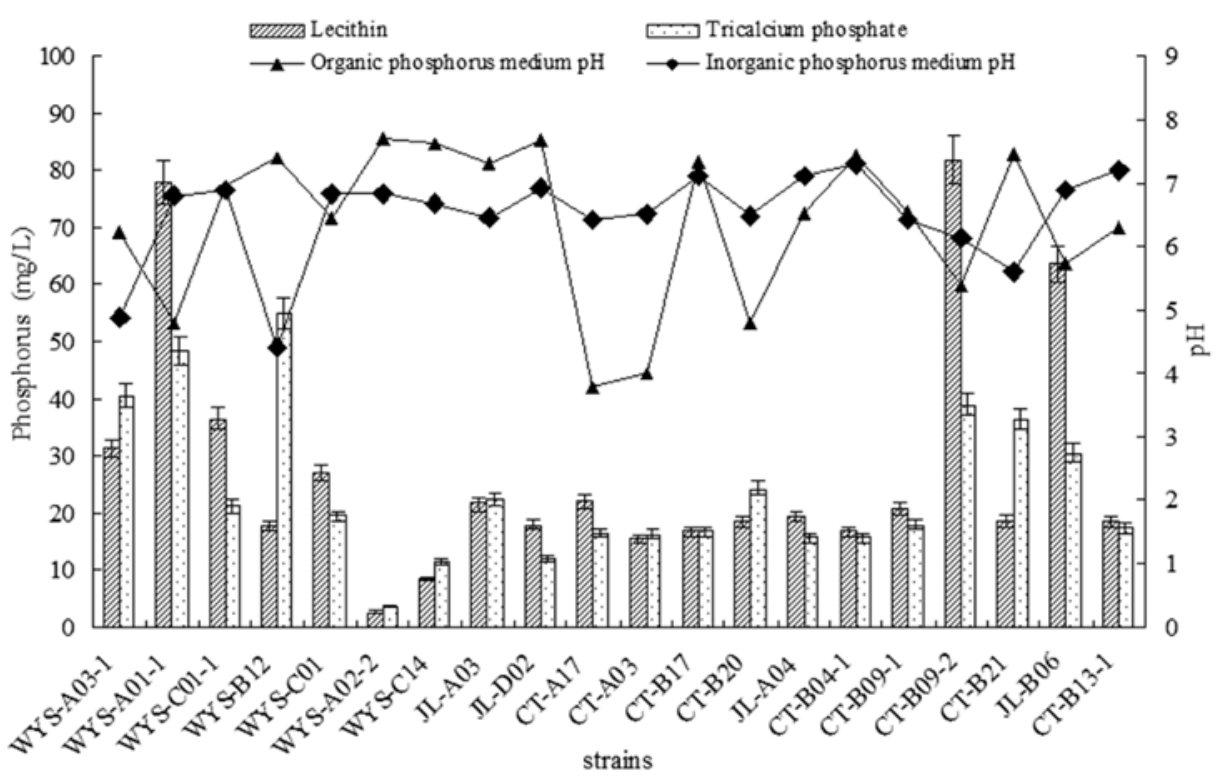

Fig. 1. The effect of endophytic bacteria in solubilizing organic phosphorus (lecithin) and inorganic phosphate (tricalcium phosphate) in the shaking flask method and on $\mathrm{pH}$ changes 
Table 2

Solubilizing potassium by endophytic bacteria using the shaking flask method

\begin{tabular}{|l|c|c|c|}
\hline \multicolumn{1}{|c|}{ Strains } & Potassium & Strains & Potassium \\
\hline WYS-A03-1 & $2.54 \pm 0.06$ & CT-A03 & $2.11 \pm 0.08$ \\
\hline WYS-A01-1 & $2.39 \pm 0.06$ & CT-B17 & $1.71 \pm 0.08$ \\
\hline WYS-C01-1 & $2.27 \pm 0.10$ & CT-B20 & $2.29 \pm 0.13$ \\
\hline WYS-B12 & $2.37 \pm 0.09$ & JL-A04 & $2.15 \pm 0.13$ \\
\hline WYS-C01 & $0.89 \pm 0.13$ & CT-B04-1 & $2.17 \pm 0.09$ \\
\hline WYS-A02-2 & $1.09 \pm 0.13$ & CT-B09-1 & $2.31 \pm 0.08$ \\
\hline WYS-C14 & $0.80 \pm 0.06$ & CT-B09-2 & $2.39 \pm 0.12$ \\
\hline JL-A03 & $2.09 \pm 0.12$ & CT-B21 & $2.81 \pm 0.08$ \\
\hline JL-D02 & $2.27 \pm 0.11$ & JL-B06 & $2.46 \pm 0.08$ \\
\hline CT-A17 & $2.17 \pm 0.09$ & CT-B13-1 & $2.13 \pm 0.04$ \\
\hline
\end{tabular}

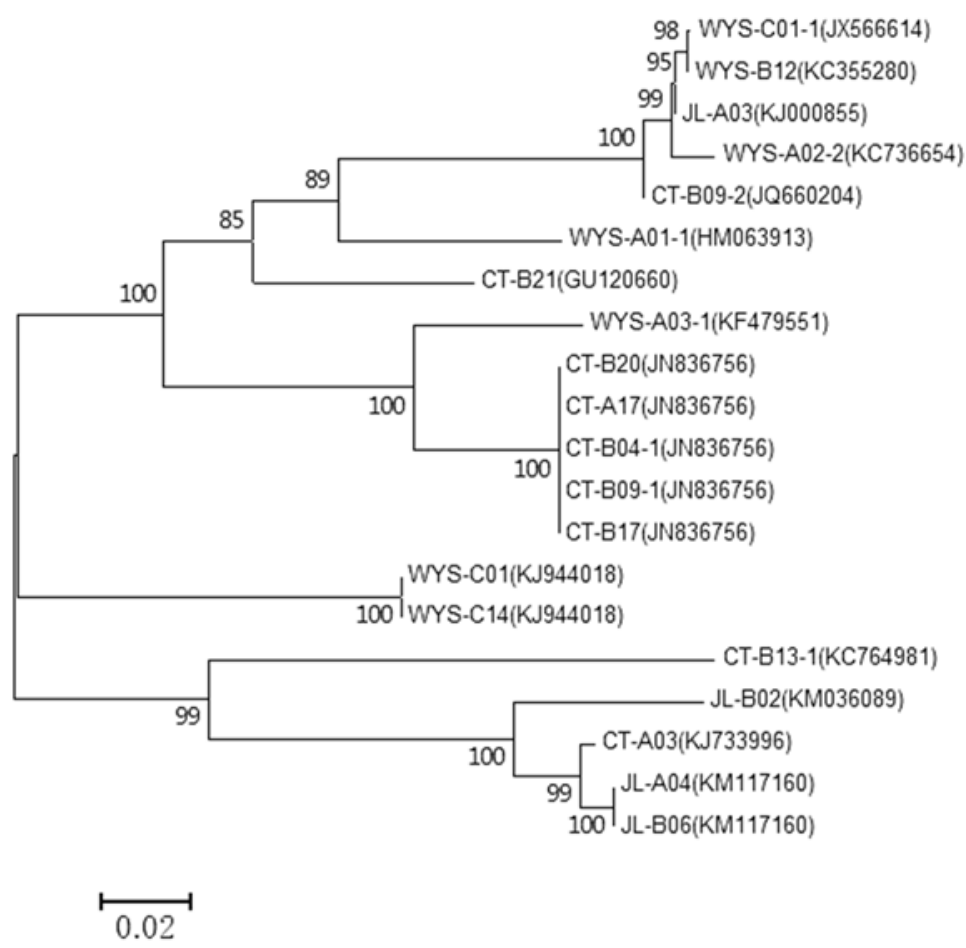

Fig. 2. Phylogenetic analysis of $16 \mathrm{~S}$ rDNA sequences of Moso Bamboo endophytic phosphorus and potassium-solubilizing bacteria 
The results on soluble potassium showed that different strains had distinct activities in solubilizing mineral potassium (potassium feldspar powder). As shown in Table 2, the soluble potassium content in the media was increased, in addition to WYS-C01, WYS-A02-2 and WYS-C14, indicating that all the endophytic bacteria were active in solubilizing mineral potassium. CT-B09-1, CT-B21, CT-B17, WYSB12, and WYS-C01-1 had strong potassium-solubilizing activity, and their soluble potassium content was $2.39-2.81 \mathrm{mg} / \mathrm{L}$. The soluble potassium content found in the medium was lower than in the CK. This was probably due to the fact that soluble potassium not only dissolves in media, but can also be accumulated in bacterial cells for growth and reproduction.

Taken together, the phosphorus- and potassium-solubilizing results using the plate method and the shake-flask method showed that CT-B09-2, WYS-A01-1 and JL-B06 had strong activities in solubilizing organic and inorganic phosphorus, and CT-B21, WYS-A03-1, JL-B06, CT-B09-2 and WYS-A01-1 had strong activities for solubilizing potassium.

Table 3

16S rDNA sequence analysis of the endophytic phosphorus and potassium-solubilizing bacteria trains

\begin{tabular}{|c|c|c|c|}
\hline Genus & Strains & Closest strains (accession no) & $\begin{array}{c}\% / \text { Sequence } \\
\text { similarity }\end{array}$ \\
\hline \multirow{5}{*}{ Alcaligenes } & CT-A17 & Alcaligenes sp. (JN836756) & 99 \\
\hline & CT-B04-1 & Alcaligenes sp. (JN836756) & 99 \\
\hline & CT-B09-1 & Alcaligenes sp. (JN836756) & 99 \\
\hline & CT-B17 & Alcaligenes sp. (JN836756) & 100 \\
\hline & CT-B20 & Alcaligenes sp. (JN836756) & 99 \\
\hline \multirow{4}{*}{ Enterobacter } & CT-B09-2 & Enterobacter sp. (JQ660204) & 99 \\
\hline & WYS-A02-2 & Enterobacter sp. (KC736654) & 99 \\
\hline & WYS-B12 & Enterobacter sp. (KC355280) & 99 \\
\hline & WYS-C01-1 & Enterobacter sp. (JX566614) & 99 \\
\hline \multirow{3}{*}{ Bacillus } & CT-A03 & Bacillus sp. (KF788188) & 100 \\
\hline & JL-A04 & Bacillus amyloliquefaciens (KM117160) & 100 \\
\hline & JL-B06 & Bacillus amyloliquefaciens (KM117160) & 100 \\
\hline Leucobacter & CT-B13-1 & Leucobacter aridicollis (KC764981) & 99 \\
\hline Pseudomonas & CT-B21 & Pseudomonas sp. (GU120660) & 99 \\
\hline Staphylococcus & JL-D02 & Staphylococcus equorum (KM036089) & 100 \\
\hline Leclercia & JL-A03 & Leclercia sp. (KJ000855) & 100 \\
\hline \multirow{2}{*}{ Ochrobactrum } & WYS-C01 & Ochrobactrum sp. (KJ944018) & 100 \\
\hline & WYS-C14 & Ochrobactrum sp. (KJ944018) & 100 \\
\hline Acinetobacter & WYS-A01-1 & Acinetobacter sp. (HM063913) & 99 \\
\hline Burkholderia & WYS-A03-1 & Burkholderia sp. (KF479551) & 100 \\
\hline
\end{tabular}


After cloning and sequencing, the 16S rDNA sequences of the 20 endophytic bacterial strains were analyzed using Blast (http:/www.ncbi.nlm.nih.gov/Blast/) to analyze the similarity between our sequences and the NCBI database in order to identify the bacterial strains in our samples. Each 16SrDNA query sequence recovered hits with known taxonomic status with more than $99 \%$ similarity as shown in Table 3.

The 20 endophytic phosphorus- and potassium-solubilizing bacterial strains belong to 14 species from 10 genera (Table 3 ). The majority of the bacteria were Alcaligenes spp., Enterobacter spp. and Bacillus spp. representing 25\%, 20\% and $15 \%$ of the total diversity of the isolated colonies, respectively. Among these, there were 6 species from 4 genera isolated from the Wuyi Mountain samples; three species from three genera isolated from the Jiangle samples; and five species from five genera isolated from the Changting samples.

\section{DISCUSSION}

In this study, the endophytic phosphorus- and potassium-solubilizing bacteria were screened from the root, rhizome, stem, and leaves of bamboo, and the diversity was analyzed using their16S rDNA sequence. The plate and the shaking flask approaches showed that the 20 phosphorus and potassium-solubilizing bacteria belong to 10 genera and 14 species, and mainly consist of members of Alcaligenes spp., Enterobacter spp. and Bacillus spp. The $16 \mathrm{~S}$ rDNA diversity results showed that bamboo has a rich population of phosphorus and potassium-solubilizing bacteria, providing a resource for the preparation and application of growth-promoting function of microbial agents.

Currently, there is a total of 89 kinds of phosphorus-solubilizing microorganisms belonging to 30 genera, in which there are 58 bacterial strains [19], including Bacillus subtilis, Escherichia spp., Erwinia spp., and Pseudomonas spp. [5, 20, 22]. Potassiumsolubilizing bacteria mainly consist of Plesiomonas spp., Bacillus mucilaginosus and Bacillus subtilis [1,7], which are capable not only of dissolving potassium feldspar, but also glass powder and apatite. The Bacillus spp. isolated within the experiment was a common bacteria in plants, but also showed the strongest activity in solubilizing phosphorus. Enterobacter spp. can be isolated from corn, cotton, rice and other plants. The Alcaligenes spp. are also found in many plants, and they were reported as enterobacter and phosphorus-solubilizing bacteria within the plant in separately studies.

Numerous studies showed that phosphorus-solubilizing bacteria secrete organic phosphorus during phosphorus deficiency, and these bacteria can dissolve insoluble phosphorus in a low $\mathrm{pH}$ environment and chelate $\mathrm{Ca}^{2+}, \mathrm{Fe}^{3+}$, and $\mathrm{Al}^{3+}$ [14]. In this study, the $\mathrm{pH}$ of the culture medium of most strains was decreased, suggesting that the strains are acid-producing, which is consistent with previous reports. However Kucey [13] and Illmer and Schinner [10] reported that the correlation between the phosphorus solubilization and phosphorus-solubilizing bacteria and $\mathrm{pH}$ was relatively weak. For certain strains, it conflicted with the observation that the lower the $\mathrm{pH}$, the higher the degree of solubilization. For example, CT-B09 (pH 3.77) had the highest phosphorus-solubilizing ability, but the $\mathrm{pH}$ was not the lowest value. CT-A17 
(pH 3.77) that had the lowest culture broth $\mathrm{pH}$ was not the one with the highest degree of lecithin decomposition. These results indicate that $\mathrm{pH}$ is an important factor, but it is not the only factor for phosphorus solubilization in bacteria, as well as that the $\mathrm{pH}$ increased in the media of WYS-B12, WYS-A02-2, JL-D02, and CT-B04-1 strains. It suggests that the microorganisms that do not produce acid may also have phosphorus solubilizing ability [21]. Some strains showed differences in D/d value, and phosphorus and potassium-solubilizing ability, indicating that the two methods are not relevant in measuring phosphorus and potassium-solubilizing capacity, and that different strains had diverse mechanisms in solubilizing phosphorus and potassium.

Endophytic phosphorus and potassium-solubilizing bacteria are the main plant growth-promoting bacteria. These beneficial microbes and plants are closely related. Research on plant growth-promoting endophytic bacteria is important in basic research and plant microbiology and has important applications in ecological agriculture and sustainable development.

\section{REFERENCES}

1. Basak, B. B., Biswas, D. R. (2009) Influence of potassium solubilizing microorganism (Bacillus mucilaginosus) and waste mica on potassium uptake dynamics by Sudan grass (Sorghum vulgare Pers.) grown under two Alfisols. Plant Soil. 317, 235-255.

2. Berg, G., Krechel, A., Ditz, M., Sikora, R. A., Ulrich, A., Hallmann, J. (2005) Endophytic and ectophytic potato-associated bacterial communities differ in structure and antagonistic function against plant pathogenic fungi. FEMS Microbiol. Ecol. 51, 215-229.

3. Gao, Z. Q., Fu, M. Y. (2006) Characteristics of seasonal changes in soil carbon and nitrogen nutrients of different Phyllostachys pubescens stands. J. Zhejiang Coll. Forest. 23, 248-254.

4. Gaulner, J. M., Feldman, A. W., Zablotowiez, R. M. (1982) Identity and behavior of xylem-residing bacteria rough lemon of florida citrus trees. Appl. Environ. Microb. 43, 1335-1342.

5. Goenadi, D. H., Siswanto, S. Y. (2000) Bioactivation of poorly soluble phosphate rocks with a phosphorus-solubilizing fungus. Soil Sci. Soc. Am. J. 64, 927-932.

6. Gothwal, R. K., Nigam, V. K., Mohanl, M. K., Samal, D., Ghosh, P. (2006) Phosphate solubilization by rhizospheric bacterial isolates from economically important desert plants. Indian J. Microb. 46, 355-361.

7. Han, H. S., Lee, K. D. (2005) Phosphate and potassium solubilizing bacteria effect on mineral uptake, soil availability and growth of eggplant. Res. J. Agri. Bio. Sci. 1, 176-180.

8. Han, S., Xia, D. L., Li, L. B., Han, J. G. (2010) Diversity of the phosphate solubilizing bacteria isolated fromthe root of Phyllostachys pubescens. J. Agricul. Univer. Hebei. 33, 26-31.

9. Huang, Q. T., Chen, A. L., He, J. (2006) Comparison of soil physical and chemical properties among various Phyllostachys pubescens plantation. J. Fujian Coll. Forest. 26, 299-302.

10. Illmer, P., Schinner, F. (1992) Solubilization of inorganic phosphates by microorganism isolated from forest siol. Soil. Biol. Biochem. 24, 389-395.

11. Ivanova, R., Bojinova, D., Nedialkova, K. (2006) Rock phosphate solubilization by soil bacteria. J. Univ. Chem. Tech. Metall. 41, 297-302.

12. Jha, B. K., Gandhi Pragash, M., Cletus, J., Raman, G., Sakthivel, N. (2009) Simultaneous phosphate solubilization potential and antifungal activity of new fluorescent pseudomonad strains, Pseudomonas aeruginosa, P. plecoglossicida and P. mosselii. World J. Microbiol. Biotechnol. 25, 573-581.

13. Kucey, R. M. N. (1988) Effect of penicillium bilaji on the solubility and uptake of P and micronutrients from soil by wheat. Can. J. siol Sci. 68, 261-270. 
14. Loveleen, R., Pankaj, K., Sudhakara, M. R. (2008) Effect of carbon and nitrogen sources on phosphate solubilization by a wild-type strain and UV-induced mutants of Aspergillus tubingensis. Curr. Microbiol. 57, 401-406.

15. Lu, L. K. (1999) Soil Agricultural Chemical Analysis Method. Chinese agricultural Science and technology Press, Beijing.

16. Mano, H., Tanaka, F., Watanabe, A., Kaga, H., Okunishi, S., Morisaki, H. (2006) Culturable surface and endophytic bacterial flora of the maturing seeds of rice plants (Oryza sativa) cultivated in a paddy field. Microb. Environ. 21, 86-100.

17. Mathurot, C., Saisamorn, L. (2009) Phosphate solubilization potential and stress tolerance of rhizbacteria from rice soil in Northern Thailand. World J. Microbiol. Biotechnol. 25, 305-314.

18. Naik, P. R., Raman, G., Narayanan, K. B., Sakthivel, N. (2008) Assessment of genetic and functional diversity of phosphate solubilizing fluorescent pseudomonads isolated from rhizospheric soil. $B M C$ Microbiol. 8, 230-243.

19. Nautiyal, C. S., Bhadauria, S. S., Kumar, P., Lal, H., Mondal, R., Verma, D. (2000) Stress induced phosphate solubilization in bacteria isolated from alkaline soils. FEMS Microbiol. Lett. 182, 291-296.

20. Oliveira, C. A., Alves, V. M. C., Marriel, I. E., Gomes, E. A., Scotti, M. R., Carneiro, N. P., Guimaraes, C. T., Schaffert, R. E., Sa, N. M. H. (2009) Phosphate solubilizing microorganisms isolated from rhizosphere of maize cultivated in an oxisol of the Brazilian Cerrado Biome. Soil Biol. Biochem. 41, 1782-1787.

21. Pandey, A., Trivedi, P., Kumar, B., Palni, L. M. (2006) Characterization of a phosphate solubilizing and antagonistic strain of Pseudomonas putida (B0) isolated from a sub-alpine location in the Indian Central Himalaya. Curr. Microbiol. 53, 102-107.

22. Rashid, M., Khalil, S., Ayub, N., Alam, S., Latif, F. (2004) Organic acids production and phosphate solubilization by phosphate solubilizing microorganisms (PSM) under in vitro conditions. Pak. J. Biol. Sci. 7, 187-196.

23. Ryan, R. P., Germaine, K., Franks, A., Ryan, D. J., Dowling, D. N. (2008) Bacterial endophytes:recent developments and application. FEMS Microbiol. Lett. 278, 1-9.

24. Selvarajm, P., Munusamy, M., Tongmin, S. (2008) Isolation and identification of phosphate solubilizing bacteria from Chinese cabbage and their effect on growth and phosphorus utilization of plants. J. Microbiol. Biotechnol. 18, 773-777.

25. Souchie, E. L., Abboud, A. C. D. (2007) Phosphate solubilization by microorganisms from the rhizosphere of Pigeonpea genotypes grown in different soil classes. Semina-Ciencias Agrarias 28, 11-18.

26. Sridevi, M., Mallaiah, K. V. (2009) Phosphate solubilization by rhizobium strains. Indian J. Microbiol. 149, 98-102.

27. Wang, G. H., Zhou, D. R., Yang, Q., Jin, J., Liu, X. B. (2005) Solubilization of rock phosphate in liquid culture by fungal isolates from rhizosphere soil. Pedosphere 15, 532-538.

28. Xu, Y. J. (2011) Research progress on pesources diversity of plant endophytes. Guangdong Agricul. Sci. 4, 149-152.

29. Zhang, L. Z., Fan, J. J., Niu, W., Li, T., Wu, R. H., Jin, Y. J. (2011) Isolation of phosphate solubilizing fungus (Aspergillus niger) from Caragana rhizosphere and its potential for phosphate solubilization. Acta. Ecol. Sin. 31, 7571-7578.

30. Zhao, X. R., Lin, Q. M., Sun, Y. X., Yao, J., Zhang, Y. S. (2001) The methods for quantifying capacity of bacteria in dissolving P compounds. Microbiology 28, 1-4. 